\title{
Vitamin D serum levels and peripheral arterial disease among southern Brazilian adults
}

\author{
Dimone Bonatto ${ }^{1,2}$ \\ Vera Maria Vieira Paniz ${ }^{2}$ \\ (iD) Clandio de Freitas Dutra \\ (iD) Ruth Liane Henn²
}

\begin{abstract}
1. Área do Conhecimento de Ciências da Vida: Universidade de Caxias do Sul, Caxias do Sul, RS, Brasil 2. Programa de Pós-Graduação em Saúde Coletiva, Universidade do Vale do Rio dos Sinos, São Leopoldo, RS, Brasil 3. Ambulatório de Cirurgia Vascular, Área do Conhecimento de Ciências da Vida: Universidade de Caxias do Sul, Caxias do Sul, RS, Brasil
\end{abstract}

http://dx.doi.org/10.1590/1806-9282.66.3.268

\section{SUMMARY}

OBJECTIVE: To investigate the association between low serum vitamin D levels and peripheral arterial disease (PAD).

METHODS: A cross-sectional study with a consecutive sample of 133 individuals from Caxias do Sul, Brasil. We considered PAD patients those with an ankle-brachial index $(A B I) \leq 0.90$ or with arterial revascularization. Vitamin D serum level was categorized as sufficient ( $\geq 30$ $\mathrm{ng} / \mathrm{mL}$ ), insufficient (>20 to $29 \mathrm{ng} / \mathrm{mL}$ ), and deficient (<20 ng/mL). Prevalence ratios $(R P)$ were calculated through Poisson regression.

RESULTS: The prevalence of PAD was 50.7\% (95\% Cl 42-59). After adjustment for potential PAD risk factors, RP were 1.08 (95\% Cl 0.661.76) for insufficient serum level and 1.57 (95\% Cl 0.96-2.57) for deficient vitamin D serum level; ( $P$ for trend $=0.020$ ).

CONCLUSION: Vitamin D serum levels showed an inverse and significant dose-response relationship with PAD.

KEYWORDS: Peripheral arterial disease. Atherosclerosis. Vitamin D. Ambulatory care. Observational study.

\section{INTRODUCTION}

Peripheral arterial disease (PAD) is among the most common causes of death by cardiovascular diseases in Brasil, with an increase of $82.1 \%$ between 1990 and $2015^{1}$. The worldwide prevalence of PAD is estimated in $10 \%$, reaching $30 \%$ among populations aged 50 years or more ${ }^{2}$. In Brasil, the prevalence of this disease is around $5 \%^{3}$.

PAD is the arterial narrowing caused by atherosclerotic lesions in the abdominal and iliac aorta, as well as in lower-body extremities ${ }^{4}$. Atherosclerotic plaques decrease blood flow and consequently lessen the oxygenation in lower-body extremities, causing claudication (pain at walking), ischemic pains at resting, ischemic ulcerations, gangrene, and may lead to amputations in advanced stages of the disease ${ }^{4-6}$.

The main risk factors for PAD are increasing age, smoking, dyslipidemia, diabetes mellitus (DM), and systemic arterial hypertension $(\mathrm{SAH})^{5,7}$. Some studies have shown that low serum levels of vitamin D may also be a risk factor for PAD onset and progression ${ }^{8-11}$.

Vitamin D deficiency is highly prevalent all over the world ${ }^{12}$. Data from studies conducted in Brazilian 
health services with adults showed that vitamin D deficiency is also high, ranging from $26.5 \%$ to $33 \%^{13,14}$.

Considering the impact of PAD on CVD mortality in Brasil, the high prevalence of lower vitamin D levels, and its possible effect on PAD occurrence, the present study aims to investigate the association between vitamin D serum levels and PAD among users of a reference outpatient clinic specialized in vascular diseases located in Caxias do Sul, Brasil. In addition, to date, we are not aware of studies that have explored this association in Brasil.

\section{METHODS}

A cross-sectional study with individuals of both sexes, aged 40 years or more, who had visited a reference public outpatient clinic specialized in vascular diseases, which provides healthcare to populations of 49 municipalities and is located in a medium-sized city in the south of Brasil.

The sample was obtained consecutively among those who attended the clinic between March 2016 and January 2017. Patients with conditions that impaired vitamin D absorption or increased needs of this vitamin (pregnant and nursing women), vegans, those in use of vitamin D supplements, and patients with poor cognition, unable to answer the questionnaire, were excluded from this study.

At the end of the data collection period, 133 subjects were recruited for the study. Considering the sample size obtained, the margin of error for prevalence estimation of $50 \%$ of PAD was about 8.0 percentage points. For the associations, the study had a power of $80 \%$ to detect prevalence ratios equal to or greater than 1.7 for exposures between $60 \%$ and $80 \%$ of the population, with a prevalence of PAD $20 \%-40 \%$ in the non-exposed, 95\% confidence level.

Patients had their records checked, and those who meet the eligibility criteria were invited to participate voluntarily in the study. Then, the patients were referred to the vascular surgeon, who measured the ankle-brachial index (ABI) using a Doppler ultrasound device (brand DV610 Medmega ${ }^{\circledR}$ ) and prescribed laboratory tests. ABI is composed of the ankle's highest systolic arterial pressure (measured at the posterior tibial artery or at the foot's dorsal artery) and the highest brachial artery systolic pressure. After the medical consultation, trained interviewers applied a standardized, pre-coded, and pre-tested questionnaire and performed the anthropometric assessment.
The interviews were carried out inside the outpatient clinic, and each patient was interviewed a single time, even if they had new medical appointments during the period of this study.

Patients were considered to have PAD if they had an $\mathrm{ABI} \leq 0.90$ or had undergone some arterial revascularization procedure. $\mathrm{ABI}$ is defined as the ratio of the ankle's highest systolic arterial pressure (measured at the posterior tibial artery or at the foot's dorsal artery) and the highest brachial artery systolic pressure.

The main exposure variable, vitamin D serum levels, was obtained from the biochemical analysis of blood samples. The serum levels were determined by the electrochemiluminescence method, using Cobas ${ }^{\circledR}$ and Roche ${ }^{\circledR}$ 's 411 devices, and rated as sufficient $(\geq 30$ $\mathrm{ng} / \mathrm{mL}$ ), insufficient (>20 a $29 \mathrm{ng} / \mathrm{mL}$ ), and deficient $(<20 \mathrm{ng} / \mathrm{mL})^{12}$.

Demographic, socioeconomic, and behavioral characteristics and comorbidities were the independent variables. Demographic variables included sex, age, skin color, and marital status. Socioeconomic variables were education and family income. Behavioral variables were frequency of physical activity and time of physical practice, smoking, and alcoholic beverages consumption. Comorbidities included general obesity, abdominal obesity, DM, dyslipidemia, and SAH. General obesity was assessed by body mass index (BMI - weight in kilograms/height in meters squared) and defined as $B M I \geq 30 \mathrm{~kg} / \mathrm{m}^{215}$. Abdominal obesity was defined as waist circumference $\geq 88 \mathrm{~cm}$ for women and $\geq 102 \mathrm{~cm}$ for men ${ }^{16}$. For other comorbidities, we considered the patient as having it if they continuously took drugs to treat it.

Data were entered into Epidata software (Epidata Association, Odense, Denmark), version 3.1, with double entry. Statistical analyses were performed using the Stata software (StataCorp, CollegeStation, Texas, United States), version 14 . The sample was described by univariate analysis (categorical variables were presented as proportion and numeric variables as average and standard deviation), and the associations of vitamin D serum levels and other explanatory variables with PAD were tested by bivariate analysis. The prevalence ratio (PR) and its respective 95\% confidence interval (95\% CI) were calculated through Poisson regression with robust variance. The association between serum levels of vitamin D and PAD was tested in eight models. Model 1 was unadjusted. Model 2 was adjusted for sex and age. Model 3 was adjusted for model 2 and smoking. Model 4 was adjusted for 
models 2 and 3 and physical activity. Model 5 was adjusted for models 2, 3, and 4, and abdominal obesity. Model 6 was adjusted for models 2, 3, 4, and 5, and DM. Model 7 was adjusted for models 2, 3, 4, 5, and 6 , and dyslipidemias. Model 8 was adjusted for models $2,3,4,5,6$, and 7 , and SAH. Variables were retained in models if they had a $P$-value $\leq 0.20$.

The project was approved by the Research Ethics Committee of Caxias do Sul University, through protocol number 1.251.714. All participants validated their participation in this research by reading and signing the Informed Consent Form.

\section{RESULTS}

In all, 144 patients fulfilled the selection criteria and underwent ankle-brachial index measurement. Of these, 11 (7.4\%) did not undergo the examination for vitamin D serum levels and were excluded from the multivariate analysis. Among those participants, we observed a higher proportion of women, aged 60 years or more, with education between 5 and 8 years, former smokers, with abdominal obesity, and no previous records of high blood pressure, DM, or dyslipidemia. However, these particularities were not statistically significant.

According to Table 1, the majority of the study participants was female (53.5\%), aged 60 years or more $(54.2 \%)$, with a mean age of $60.7 \pm 11.1$ years, white (65.3\%), with a partner (52.3\%), up to four years of education (41.6\%), and earned more than BRL 2,000.00 per month. With regard to behavioral variables, $48.6 \%$ were former smokers, $66.7 \%$ did not practice physical activities, and 52.1\% did not drink alcoholic beverages. In relation to comorbidities, general and abdominal obesity affected $42 \%$ and $62.7 \%$ of the participants, respectively; $22.2 \%$ had DM, 50.7\% had dyslipidemia, and $61.1 \%$ had SAH. Vitamin D insufficiency and deficiency prevalences were $36.1 \%$ (95\% CI 28-44) and 45.1\% (95\% CI 36-53), respectively.

PAD prevalence was 50.7\% (95\% CI 42-59). This condition increased linearly with age and was higher among men, smokers, and former smokers, among patients with DM, SAH, dyslipidemia, and among participants with insufficient and deficient vitamin D levels. In the crude analysis, PAD showed an inverse dose-response relationship with vitamin $\mathrm{D}$ serum levels $(p=0.028)$. The PR for PAD among individuals with insufficient and deficient vitamin D levels were 1.27 (95\% CI 0.69-2.34) and 1.71 (95\% CI 0.98-3.00), respectively (Table 1$)$.

Figure 1 describes the prevalence of PAD according to serum 25OHD concentrations. The highest prevalence was observed in the deficient vitamin D serum

TABLE 1. SAMPLE CHARACTERISTICS, PREVALENCE AND PREVALENCE RATIO OF PERIPHERAL ARTERIAL DISEASE AMONG USERS OF A REFERENCE OUTPATIENT CLINIC SPECIALIZED IN VASCULAR DISEASES IN CAXIAS DO SUL, BRASIL $(N=144)$.

\begin{tabular}{|c|c|c|c|c|c|}
\hline Variable & n (\%) & $\%$ PAD & PR & $95 \% \mathrm{Cl}$ & $P$ value \\
\hline Total: & $144(100)$ & 50.7 & - & (42.4-59.0) & - \\
\hline Sex & & & & & $<0.001 a$ \\
\hline Female & 77 (53.5) & 23.4 & 1.00 & & \\
\hline Male & $67(46.5)$ & 82.1 & 3.51 & $(2.30-5.35)$ & \\
\hline Age (years) & & & & & $<0.001 b$ \\
\hline $40-49$ & $27(18.7)$ & 25.9 & 1.00 & & \\
\hline $50-59$ & $39(27.1)$ & 38.5 & 1.48 & $(0.70-3.15)$ & \\
\hline$\geq 60$ & $78(54.2)$ & 65.4 & 2.52 & $(1.14-5.55)$ & \\
\hline Color of skin & & & & & $0.903 a$ \\
\hline White & $94(65.3)$ & 51.1 & 1.00 & & \\
\hline Non-white & $50(34.7)$ & 50.0 & 0.98 & $(0.70-1.38)$ & \\
\hline Marital Status & & & & & $0.745 a$ \\
\hline With partner & $75(52.3)$ & 52.0 & 1.00 & & \\
\hline Without partner & $69(47.7)$ & 49.3 & 0.95 & $(0.68-1.31)$ & \\
\hline Education (years) & & & & & $<0.093 b$ \\
\hline$\geq 9$ & $26(18.1)$ & 46.2 & 1.00 & & \\
\hline $5-8$ & $58(40.3)$ & 41.4 & 0.90 & $(0.53-1.50)$ & \\
\hline $0-4$ & $60(41.6)$ & 61.7 & 1.34 & $(0.84-2.12)$ & \\
\hline
\end{tabular}




\begin{tabular}{|c|c|c|c|c|c|}
\hline Variable & $n(\%)$ & $\%$ PAD & PR & $95 \% \mathrm{Cl}$ & P value \\
\hline Per capita income (tertiles) & & & & & $<0.969 b$ \\
\hline I < BRL 1,400.00 & $34(23.6)$ & 52.9 & 1.00 & & \\
\hline II BRL 1,400.00 - 2,000.00 & $50(34.7)$ & 48.0 & 0.91 & $(0.59-1.39)$ & \\
\hline III >BRL 2,000.00 & $60(41.7)$ & 51.7 & 0.98 & $(0.65-1.46)$ & \\
\hline Smoking & & & & & $<0.001 b$ \\
\hline Never smoked & $51(35.4)$ & 27.5 & 1.00 & & \\
\hline Ex-smoker & $70(48.6)$ & 64.3 & 2.34 & $(1.45-3.79)$ & \\
\hline Smoker & $23(16.0)$ & 60.9 & 2.22 & $(1.27-3.86)$ & \\
\hline Physical Activity (quantity) & & & & & $0.129 b$ \\
\hline Practice $\geq 150 \mathrm{~min} /$ week & $22(15.2)$ & 56.2 & 1.00 & & \\
\hline Practice < $150 \mathrm{~min} /$ week & $26(18.1)$ & 38.5 & 0.94 & $(0.47-1.89)$ & \\
\hline Do not practice & $96(66.7)$ & 40.9 & 1.37 & $(0.81-2.35)$ & \\
\hline Physical Activity (time) & & & & & $0.064 b$ \\
\hline Practices for $>12$ months & $41(27.0)$ & 35.5 & 1.00 & & \\
\hline Practices for $\leq 12$ months & $7(5.6)$ & 47.1 & 1.32 & $(0.66-2.66)$ & \\
\hline Do not practice & $96(67.4)$ & 56.2 & 1.58 & $(0.95-2.63)$ & \\
\hline Alcoholic beverages consumption & & & & & $0.710 b$ \\
\hline Do not drink & $75(52.1)$ & 52.0 & 1.00 & & \\
\hline \multirow{2}{*}{$\begin{array}{l}<30 \mathrm{~g} / \text { day } \mathrm{o}^{\lambda} \text { and }<15 \mathrm{~g} / \text { day } q \\
\geq 30 \mathrm{~g} / \text { day } \mathrm{o}^{\lambda} \text { and } \geq 15 \mathrm{~g} / \text { day } q\end{array}$} & $56(38.9)$ & 44.6 & 0.86 & $(0.87-2.03)$ & \\
\hline & $13(9.0)$ & 69.2 & 1.33 & $(0.87-2.03)$ & \\
\hline General obesity & & & & & $0.090 a$ \\
\hline No & $83(58.0)$ & 56.3 & 1.00 & $(0.52-1.05)$ & \\
\hline Yes & $60(42.0)$ & 41.7 & 0.73 & & \\
\hline Abdominal obesity & & & & & $0.068 a$ \\
\hline No & $53(37.3)$ & 60.4 & 1.00 & $(0.54-1.02)$ & \\
\hline Yes & $89(62.7)$ & 44.9 & 0.74 & & \\
\hline Diabetes Mellitus & & & & & $<0.001 a$ \\
\hline No & $112(77.8)$ & 42.9 & 1.00 & $(1.37-2.42)$ & \\
\hline Yes & $32(22.2)$ & 78.1 & 1.82 & & \\
\hline Dyslipidemias & & & & & $<0.001 a$ \\
\hline No & $71(49.3)$ & 25.3 & 1.00 & $(1.95-4.53)$ & \\
\hline Yes & $73(50.7)$ & 75.3 & 2.97 & & \\
\hline Hypertension & & & & & $0.008 a$ \\
\hline No & $56(38.9)$ & 35.7 & 1.00 & $(1.14-2.49)$ & \\
\hline Yes & $88(61.1)$ & 60.3 & 1.68 & & \\
\hline Vitamin D serum levels ( $\mathrm{ng} / \mathrm{ml}$ ) & & & & & $0.028 b$ \\
\hline Sufficient & $25(18.8)$ & 36.0 & 1.00 & $(0.69-2.34)$ & \\
\hline Insufficient & $48(36.1)$ & 45.8 & 1.27 & $(0.98-3.00)$ & \\
\hline Deficient & $60(45.1)$ & 61.7 & 1.71 & $(0.98-3.00)$ & \\
\hline
\end{tabular}

PAD - Peripheral arterial disease, PR - Prevalence ratio, Cl - 95\% Confidence Interval. Wald test for heterogeneity, b Wald test for linear tendency

level (61.7\%) and the lowest was in the sufficient serum level $(36.0 \%)(p=0.021)$.

Table 2 shows the PRs for PAD. The inverse dose-response relationship between vitamin D serum levels and PAD remained significant among the different adjustment models, but with a reduction in the magnitude of the effect measure. In the last model, after adjustment for potential PAD risk factors investigated in the present study, PRs were 1.08 (95\% CI 0.66-1.76) for insufficient serum level and 1.57 (95\% CI 0.96-2.57) for deficient vitamin D serum level; $(p$ for linear trend $=0.020$ ).

\section{DISCUSSION}

In the present study, the prevalences of vitamin D deficiency and of PAD were high. Vitamin D serum levels showed an inverse and significant dose-response relationship with PAD. In the model adjusted for all risk factors, PAD probability was $57 \%$ higher among participants with deficiency when compared to those with a sufficient serum level.

The high prevalence of PAD found in this study (50.7\%) is consistent with the data obtained in specialized health services, where values ranged from 51\% 
TABLE 2. PREVALENCE RATIO OF PERIPHERAL ARTERIAL DISEASE AND 95\% CONFIDENCE INTERVAL, ACCORDING TO DIFFERENT ANALYSIS MODELS, AMONG USERS OF A REFERENCE OUTPATIENT CLINIC SPECIALIZED IN VASCULAR DISEASES IN CAXIAS DO SUL, BRASIL. $(N=133)$

\begin{tabular}{|c|c|c|c|c|c|c|c|c|}
\hline Variable & $\begin{array}{l}\text { Model } 1 \\
\text { P-value } \\
\text { PR }(95 \% \mathrm{Cl})\end{array}$ & $\begin{array}{l}\text { Model } 2 \\
\text { P-value } \\
\text { PR }(95 \% \mathrm{Cl})\end{array}$ & $\begin{array}{l}\text { Model } 3 \\
\text { P-value } \\
\text { PR }(95 \% \mathrm{Cl})\end{array}$ & $\begin{array}{l}\text { Model } 4 \\
\text { P-value } \\
\text { PR }(95 \% \mathrm{Cl})\end{array}$ & $\begin{array}{l}\text { Model } 5 \\
\text { P-value } \\
\text { PR }(95 \% \mathrm{Cl})\end{array}$ & $\begin{array}{l}\text { Model } 6 \\
\text { P-value } \\
\text { PR }(95 \% \mathrm{Cl})\end{array}$ & $\begin{array}{l}\text { Model } 7 \\
\text { P-value } \\
\text { PR }(95 \% \mathrm{Cl})\end{array}$ & $\begin{array}{l}\text { Model } 8 \\
\text { P-value } \\
\text { PR }(95 \% \mathrm{Cl})\end{array}$ \\
\hline $\begin{array}{l}\text { Vitamin D } \\
\text { serum levels } \\
\text { (ng/ml) } \\
\text { Sufficient } \\
\text { Insufficient } \\
\text { Deficient }\end{array}$ & $\begin{array}{c}0.028 a \\
1.00 \\
1.27(0.69-2.34) \\
1.71(0.98-3.00)\end{array}$ & $\begin{array}{c}0.035 a \\
1.00 \\
1.08(0.65-1.81) \\
1.50(0.92-2.46)\end{array}$ & $\begin{array}{c}0.037 a \\
1.00 \\
1.11(0.66-1.88) \\
1.51(0.92-2.50)\end{array}$ & $\begin{array}{c}0.038 a \\
1.00 \\
1.08(0.65-1.81) \\
1.50(0.92-2.44)\end{array}$ & $\begin{array}{c}0.036 a \\
1.00 \\
1.07(0.64-1.77) \\
1.53(0.93-2.52)\end{array}$ & $\begin{array}{c}0.042 \mathrm{a} \\
1.00 \\
1.06(0.63-1.78) \\
1.52(0.91-2.55)\end{array}$ & $\begin{array}{c}0.014 a \\
1.00 \\
1.08(0.67-1.75) \\
1.60(0.99-2.58)\end{array}$ & $\begin{array}{c}0.020 a \\
1.00 \\
1.08(0.66-1.76) \\
1.57(0.96-2.57)\end{array}$ \\
\hline
\end{tabular}

PR - Prevalence Ratio, 95\% Cl - 95\% Confidence Interval, a Wald test for the linear tendency. Model $1=$ no adjustment. Model $2=$ adjusted for sex and age. Model $3=$ adjusted for sex, age and smoking. Model 4 = adjusted for sex, age, smoking, and practice time of PA. Model $5=$ adjusted for sex, age, smoking, practice time of PA, and abdominal obesity. Model $6=$ adjusted for sex, age, smoking, practice time of PA, abdominal obesity and DM. Model $7=$ adjusted for sex, age, smoking, practice time of PA, abdominal obesity, DM and dyslipidemias. Model $8=$ adjusted for sex, age, smoking, practice time of PA, abdominal obesity, DM, dyslipidemias, and hypertension.

PA - Physical Activity; DM - Diabetes Mellitus.

to $75 \%{ }^{17,18}$. It should be noted that both the method for PAD diagnosis as well as the participants' mean age were similar to those in the present study.

The inverse dose-response relationship between the vitamin D serum levels and PAD found in the present study is supported by literature data, although with different outlines, populations, and cut-off points for rating vitamin D serum levels ${ }^{8-11}$. In the United States, data on 5,000 individuals aged 40 years or more, researched by the National Health and Nutrition Examination Survey (NHANES) ${ }^{9}$, showed that the lower the vitamin D serum level, the higher the chances of PAD ( $\mathrm{p}<0.001)$. The adjusted OR was 1.80 (95\% CI 1.19-2.74) for individuals rated in the lowest quartile $(<17.8 \mathrm{ng} / \mathrm{mL})$ when compared to the highest quartile of this vitamin $(\geq 29.2 \mathrm{ng} / \mathrm{mL})^{9}$. PAD incidence according to vitamin D serum levels was researched at the Atherosclerosis Risk in Communities Study (ARIC) ${ }^{19}$, a cohort study; 11,789 patients were assessed. The results, adjusted for sociodemographic and behavioral variables, showed that PAD risk increased linearly and inversely with vitamin D serum levels $(p=0.02)$. However, when biochemical parameters (HDL-col, LDL-col and C-reactive protein), comorbidities (DM and SAH), and the use of drugs for cholesterol and $\mathrm{SAH}$ were included in the analysis, the association lost statistical significance. The authors believe this result is due to the mediation role these factors may play in the vitamin D and PAD relationship, which could attenuate its effect ${ }^{19}$. A meta-analysis of observational studies with data of 6,418 participants showed that the vitamin D serum levels were significantly lower among individuals suffering from PAD when compared to others without this condition (standardized mean difference $=-0.32 ; 95 \% \mathrm{CI}:-0.58 ;-0.05 ; \mathrm{p}=0.02)^{20}$.

Other studies also assessed the association between vitamin $\mathrm{D}$ and $\mathrm{PAD}$, however, without considering exposure as a categorical ordinal or continuous variable. In Israel, a cross-sectional study with 8,175 men (mean age $55 \pm 17$ years) and 26,699 women (mean age $55 \pm 15$ years), all of them users of a health system, showed that the ROs of PAD were 1.35 (95\% CI 0.88-2.07; $p=0.175)$ and 1.31 (95\% CI 0.87-1.98; $\mathrm{p}=0.198$ ), respectively, for men and women classified in the average level of vitamin $\mathrm{D}(\geq 15 \mathrm{ng} / \mathrm{mL}$ to $<30 \mathrm{ng} / \mathrm{mL}$ ), compared to those at the highest level $(\geq 30 \mathrm{ng} / \mathrm{mL})$. When the lowest level of vitamin $\mathrm{D}(<15 \mathrm{ng} / \mathrm{mL})$ was compared to the highest level of vitamin D, the ROs were 1.73 (95\% CI 1.05-2.84; $\mathrm{p}=0.031$ ) for men and 1.85 (95\% CI 1.17-2.91; $\mathrm{p}=0.008)$ for women ${ }^{8}$. Also conducted among users of a health service, a cohort study researched the incidence of PAD and vitamin D serum levels in the state of Utah, in the United States. About 42,000 electronic patient records were assessed (users mean age of $55 \pm 21$ years). The adjusted risk of PAD was 1.01 (95\% CI 0.78-1.31; $p=0.93$ ) among those with a lower serum level (16 to $30 \mathrm{ng} / \mathrm{mL}$ ) and 1.42 (95\% CI 1.04-1.94; $p=0.03$ ) among those with

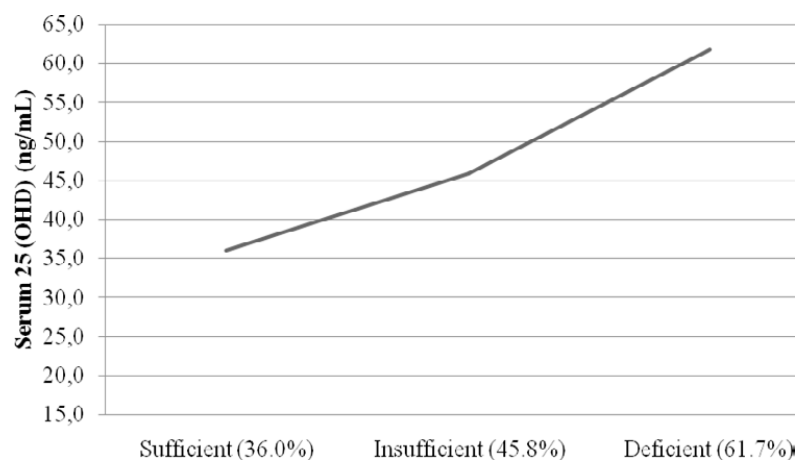

FIGURE 1. PREVALENCE OF PERIPHERAL ARTERIAL DISEASE (PAD) ACCORDING TO SERUM VITAMIN D LEVELS AMONG USERS OF A REFERENCE OUTPATIENT CLINIC SPECIALIZED IN VASCULAR DISEASES IN CAXIAS DO SUL, BRASIL (N=133). *TEST FOR LINEAR TREND. $P<0.05$. 
a very low serum level $(<16 \mathrm{ng} / \mathrm{mL})$ when compared to individuals with regular vitamin D serum levels $(>30 \mathrm{ng} / \mathrm{mL})^{10}$. Based on these results, which showed no association between the intermediary vitamin $D$ level and PAD, we conducted an analysis where the vitamin D serum level was dichotomized in order to isolate the deficient category (sufficient/insufficient and deficient). We observed that the association between vitamin $D$ and PAD remained significant across all adjustment models. In the last model, the probability of PAD was $46 \%$ higher (1.46; 95\% CI 1.13-1.90; $p=0.04$ ) among individuals with deficient serum levels when compared to those with sufficient/insufficient serum levels (data not displayed on the table). This result and those in the mentioned studies lead one to think that vitamin D deficiency - more than its insufficiency - would be the risk factor for PAD. However, this must be cautiously stated, since these studies considered different cutoff points for rating vitamin D serum levels. Another aspect to be considered is that, although dichotomization increased the precision of effect measurement, this was smaller than the one obtained in the analysis considering vitamin $\mathrm{D}$ as an ordinal categorical variable (PR 1.46 vs. PP 1.57). Besides, from a public health point of view, it would be more useful to consider the dose-response relationship between vitamin $\mathrm{D}$ and $\mathrm{PAD}$, since intervention measures for increasing vitamin D serum levels could be implemented earlier among individuals presenting insufficiency for this vitamin.

Conversely, other studies have not been able to show an association between vitamin $\mathrm{D}$ and PAD. In the multiple linear regression analysis of data from 275 Australian users of a hospital cardiology sector (75 of them PAD patients), with a median age of $66 \pm 11.2$ years, the vitamin D serum level was not a PAD predictor. The researchers ascribed this result to the small number of individuals suffering from PAD; however, they represented $27.3 \%$ of the sample ${ }^{17}$. A cross-sectional study, conducted in the USA, selected 402 PAD patients (median age of $73.1 \pm 7.7$ years) and 305 participants who were free from this condition (median age of $70.2 \pm 7.2$ years) in medical services. The average vitamin $D$ serum level was lower among PAD patients ( $53.7 \pm 24.9$ nmo$\mathrm{l} / \mathrm{L}$ ) when compared to PAD free individuals ( $54.6 \pm 23.7$ $\mathrm{nmol} / \mathrm{L}$ ); however, the difference was not statistically significant $(\mathrm{p}=0.63)$. According to the authors, patients without PAD also had lower vitamin D serum levels, and this could be explained by the high prevalence of chronic conditions among them ${ }^{21}$.

The studies described here so far indicate controversial results regarding the relationship between vitamin D serum levels and PAD, but the differences among the studied populations, as well as the ratings and analysis performed could account for these results. In Brasil, as far as we are aware, this association has not been researched. Since PAD has been an important CVD cause of death, with almost double the prevalence in the last decades, and may occur through different mechanisms, it is fundamental to verify vitamin $\mathrm{D}$ as a predictor of its onset and progression as a way of helping strategies to prevent these mechanisms.

The role of vitamin $\mathrm{D}$ in the onset of PAD may take place through different biological mechanisms. Directly, vitamin D affects atherosclerosis through its effect on endothelial function, modulating the inflammatory process, and producing smooth muscle cells ${ }^{22}$. Indirectly, vitamin D effect takes place through its operation on PAD risk factors, such as SAH, DM, and dyslipidemia $^{23-25}$. In relation to $\mathrm{SAH}$, it is observed that lower levels of this vitamin lead to an increase in vascular rigidity through the renin-angiotensin-aldosterone system activation ${ }^{23}$. Regarding DM, individuals with vitamin $D$ deficiency have a dysfunction in the pancreas beta cells, which produces modifications in insulin secretion, creating resistance to this hormone ${ }^{24}$. In dyslipidemias, vitamin D deficiency favors the capture of LDL-cholesterol molecules oxidized by macrophages ${ }^{7,25}$.

This study shows that low serum vitamin D levels may be an independent risk factor for the development of PAD. However, it is plausible to think of the indirect effect it may have on the onset of PAD since the attenuation of effect measures observed after adjustment for DM and SAH could indicate that part of this effect may have been mediated by these factors ${ }^{19,22}$.

Our results should be interpreted in light of certain limitations. Firstly, the small number of individuals resulted in low accuracy of effect measures, which can be observed by the $95 \% \mathrm{CI}$ amplitude on main exposure categories. Nevertheless, since explanatory analysis between the main exposure and the outcome showed a dose-response effect, vitamin D remained categorized as sufficient, insufficient, and deficient, in order to emphasize the biological gradient verified in the bivariate analysis. Secondly, the inherent reverse causality of cross-sectional studies cannot be discarded. If so, individuals suffering from PAD may have less sun exposure because of the disease's complications, resulting in lower vitamin D serum levels. Another limitation is the fact that vitamin D daily intake wasn't evaluated. Longitudinal studies could clarify this relation. 


\section{CONCLUSION}

Our findings support the association between insufficient and deficient vitamin D serum levels and PAD, and, as far as we know, this is the first Brazilian study to research such association. Considering the high prevalence of lower vitamin D serum levels, their direct effect on PAD, as well as in the occurrence of mediator risk factors for this and other cardiovascular diseases, it is important to encourage the population to seek sufficient and adequate sun exposure and as well to intake vitamin-D-rich food.

\section{RESUMO}

OBJETIVO: Investigar a associação entre níveis séricos de vitamina D e doença arterial obstrutiva periférica (DAOP).

MÉTODOs: Estudo transversal, com amostra consecutiva de 133 indivíduos. Foram considerados com DAOP pacientes com índice tornozelo braquial $\leq 0,90$ ou com revascularização arterial. O nível sérico de vitamina D foi classificado em: suficiente ( $\geq 30 \mathrm{ng} / \mathrm{mL}$ ), insuficiente (>20 a $29 \mathrm{ng} / \mathrm{mL}$ ) e deficiente ( $<20 \mathrm{ng} / \mathrm{mL}$ ). Razões de Prevalência (RP) foram calculadas por meio de regressão de Poisson. RESULTADOS: A prevalência de DAOP foi de 50,7\% (IC95\% 42-59). Após ajuste para potenciais fatores de risco para DAOP, as RP foram de 1,08 (IC95\% 0,66-1,76) para nível sérico insuficiente e de 1,57 (IC95\% 0,96-2,57) para o nível sérico deficiente de vitamina D; ( $p$ para tendência $=0,020)$.

CONCLUSÃO: O nível sérico de vitamina D mostrou uma relação dose/resposta inversa e significativa com DAOP.

PALAVRAS-CHAVE: Doença arterial periférica. Aterosclerose. Vitamina D. Assistência ambulatorial. Estudo observacional.

\section{REFERENCES}

1. Brant LCC, Nascimento BR, Passos VMA, Duncan BB, Bensenõr IJM, Malta $D C$, et al. Variations and particularities in cardiovascular disease mortality in Brasil and Brazilian states in 1990 and 2015: estimates from the Global Burden of Disease. Rev Bras Epidemiol. 2017;20(Suppl 01):116-28.

2. Fowkes FG, Rudan D, Rudan I, Aboyans V, Denenberg |O, McDermott MM, et al. Comparison of global estimates of prevalence and risk factors for peripheral artery disease in 2000 and 2010: a systematic review and analysis. Lancet. 2013;382(9901):1329-40.

3. Alvim RO, Dias FAL, Oliveira CM, Horimoto ARVR, Ulbrich AZ, Krieger JE, et al. Prevalência de doença arterial periférica e fatores de risco associados em uma população rural brasileira: estudo corações de Baependi. Int | Cardiovasc Sci. 2018;31(4):405-13.

4. Schorr EN, Treat-Jacobson D. Methods of symptom evaluation and their impact on peripheral artery disease (PAD) symptom prevalence: a review. Vasc Med. 2013;18(2):95-111.

5. Hennion DR, Siano KA. Diagnosis and treatment of peripheral arterial disease. Am Fam Physician. 2013;88(5):306-10.

6. Mascarenhas JV, Albayati MA, Shearman CP, Jude EB. Peripheral arterial disease. Endocrinol Metab Clin North Am. 2014;43(1):149-66.

7. Muller MD, Reed AB, Leuenberger UA, Sinoway LI. Physiology in medicine: peripheral arterial disease. J Appl Physiol (1985). 2013;115(9):1219-26.

8. Steinvil A, Leshem-Rubinow E, Berliner S, Justo D, Finn T, Ish-Shalom M, et al. Vitamin D deficiency prevalence and cardiovascular risk in Israel. Eur I Clin Invest. 2011;41(3):263-8.

9. Melamed ML, Muntner P, Michos ED, Uribarri J, Weber C, Sharma J, et al. Serum 25-hydroxyvitamin $D$ levels and the prevalence of peripheral arterial disease: results from NHANES 2001 to 2004. Arterioscler Thromb Vasc Biol. 2008;28(6):1179-85.

10. Anderson JL, May HT, Horne BD, Bair TL, Hall NL, Carlquist JF, et al; Intermountain Heart Collaborative (IHC) Study Group. Relation of vitamin D deficiency to cardiovascular risk factors, disease status, and incident events in a general healthcare population. Am J Cardiol. 2010;106(7):963-8.

11. Oh SH, Kweon SS, Choi JS, Rhee JA, Lee YH, Nam HS, et al. Association between vitamin $D$ status and risk of peripheral arterial disease: the Dong-gu study. Chonnam Med J. 2016;52(3):212-6.

12. Holick MF, Binkley NC, Bischoff-Ferrari HA, Gordon CM, Hanley DA, Heaney RP, et al; Endocrine Society. Evaluation, treatment, and prevention of vitamin D deficiency: an endocrine society clinical practice guideline. J Clin Endocrinol Metab. 2011;96(7):1911-30.

13. Neves JP, Silva AS, Morais LC, Diniz AS, Costa MI, Asciutti LS, et al. 25-hydroxyvitamin D concentrations and blood pressure levels in hypertensive elderly patients. Arq Bras Endocrinol Metabol. 2012;56(7):415-22.
14. Martins IS, Palhares MO, Teixeira OC, Gontijo Ramos M. Vitamin D status and its association with parathyroid hormone concentration in Brazilians. J Nutr Metab. 2017;2017:9056470.

15. Obesity: preventing and managing the global epidemic. Report of a WHO consultation. World Health Organ Tech Rep Ser. 2000;894:i-xii, 1-253.

16. National Cholesterol Education Program (NCEP) Expert Panel on Detection, Evaluation, and Treatment of High Blood Cholesterol in Adults (Adult Treatment Panel III). Third Report of the National Cholesterol Education Program (NCEP) Expert Panel on Detection, Evaluation and Treatment of High Blood Cholesterol in Adults (Adult Treatment Panel III) final report. Circulation. 2002;106(25):3143-421.

17. Liew JY, Sasha SR, Ngu PJ, Warren JL, Wark J, Dart AM, et al. Circulating vitamin $D$ levels are associated with the presence and severity of coronary artery disease but not peripheral arterial disease in patients undergoing coronary angiography. Nutr Metab Cardiovasc Dis. 2015;25(3):274-9.

18. Zagura M, Serg M, Kampus P, Zilmer M, Eha J, Unt E, et al. Aortic stiffness and vitamin $D$ are independent markers of aortic calcification in patients with peripheral arterial disease and in healthy subjects. Eur J Vasc Endovasc Surg. 2011;42(5):689-95

19. Rapson IR, Michos ED, Alonso A, Hirsch AT, Matsushita K, Reis JP, et al. Serum 25-hydroxyvitamin $D$ is associated with incident peripheral artery disease among white and black adults in the ARIC study cohort. Atherosclerosis. 2017;257:123-9.

20. Nsengiyumva V, Fernando ME, Moxon JV, Krishna SM, Pinchbeck J, Omer $\mathrm{SM}$, et al. The association of circulating 25-hydroxyvitamin D concentration with peripheral arterial disease: a meta-analysis of observational studies. Atherosclerosis. 2015;243(2):645-51.

21. McDermott MM, Liu K, Ferrucci L, Tian L, Guralnik J, Kopp P, et al. Vitamin $\mathrm{D}$ status and functional performance in peripheral artery disease. Vasc Med. 2012;17(5):294-302

22. Kassi E, Adamopoulos C, Basdra EK, Papavassiliou AG. Role of vitamin D in atherosclerosis. Circulation. 2013;128(23):2517-31.

23. Kienreich K, Grubler M, Tomaschitz A, Schmid I, Verheyen N, Rutters F, et al. Vitamin D, arterial hypertension \& cerebrovascular disease. Indian J Med Res. 2013;137(4):669-79.

24. Bland R, Markovic D, Hills CE, Hughes SV, Chan SL, Squires PE, et al. Expression of 25-hydroxyvitamin D3-1alpha-hydroxylase in pancreatic islets. J Steroid Biochem Mol Biol. 2004;89-90(1-5):121-5.

25. Sakakura K, Nakano M, Otsuka F, Ladich E, Kolodgie FD, Virmani R. Pathophysiology of atherosclerosis plaque progression. Heart Lung Circ. 2013;22(6):399-411. 